\title{
THE PARTICIPATION OF INDIGENOUS AUSTRALIANS IN LEGAL EDUCATION
}

\author{
DANIEL LAVERY*
}

\section{INTRODUCTION}

This paper is based on a survey of Australian law schools in 1990-91 which sought to investigate the interface between indigenous Australians and law studies. The survey was prompted by similar recent research conducted in Canada. The focus of this paper is the Australian data but a review of the Canadian scene will be given to show the depth of field which exists. The Australian survey results will be first presented. A survey of the Canadian scene will follow with the interest being on the special entrance schemes available to Indian, Metis and Inuit peoples and the existence and operation of pre-law programmes in Canada. Although this paper cannot purport to be truly comparative, comparisons and contrasts will be drawn where possible. Some general conclusions will then be drawn with a particular emphasis on one aspect of the legal education of aboriginal peoples which is not present in the Australian analysis, that of an intensive nationally-based pre-law preparatory programme. It will be argued that, as a matter of priority, efforts should be directed to the establishment of such a programme in Australia.

A note of caution should also be firmly struck at the outset. This paper is from the perspective of a Euro-Australian lawyer within the dominant legal culture. This writer cannot, and does not purport to, give the indigenous perspective. 


\section{THE AUSTRALIAN SURVEY}

In late 1990 and early 1991 a detailed questionnaire was sent to the Deans of all Australian law schools while the writer was pursuing graduate studies at the University of Ottawa in Ontario, Canada. The survey questionnaire contained 14 questions with numerous subquestions. Survey focus was on three principal areas: the number of indigenous students who have completed or are completing studies in law, the availability of discretionary entrance schemes for Aboriginal and Torres Strait Islander persons to study law, and the availability of any pre-law programmes designed to assist such students to prepare for the study of law. ${ }^{1}$ The questionnaire also sought information on other areas such as whether any specific courses were offered on the legal rights of indigenous peoples, and if so, when such courses commenced, how frequently they are offered, if such rights were treated in other substantive courses, (for example, whether indigenous rights to land were canvassed in Land or Real Property), whether the law school had ever organised conferences on indigenous legal rights, and the like. Although these matters are only tangentially relevant to this paper, the information gathered by the survey allowed as complete a picture as has yet been obtained.

Of the twenty law schools to which the survey questionnaire was sent, eighteen responded. Generally, the quality of the survey responses was very high. However, several errors by the respondent law schools were found. In the main, these errors related to the number of indigenous students who had graduated from the institution and arose principally because records of these matters were not maintained until fairly recent times.

The covering letter to the survey requested a response on any matters upon which the law school was interested or felt compelled to enlarge. One of the areas within the questionnaire which specifically asked for additional comment was the question whether discretionary entrance schemes at the relevant institutions were successful. The additional commentary given by the law schools was very relevant to the specific recommendations of this paper. All responses are to the end of the 1990 academic year. The first aspect of the information which the questionnaire sought was the number of Aboriginal and Islander students currently enrolled in the law 
schools, both graduate and undergraduate, and also the total number of indigenous law graduates. These figures are set out in Table 1.

TABLE 1

\begin{tabular}{|c|c|c|c|}
\hline University Law School & $\begin{array}{c}\text { Under- } \\
\text { graduates }\end{array}$ & $\begin{array}{c}\text { Post- } \\
\text { graduates }\end{array}$ & $\begin{array}{c}\text { Total no. } \\
\text { of A. \& I. } \\
\text { graduates } \\
\text { to } 1990\end{array}$ \\
\hline Adelaide & 4 & 0 & 2 \\
\hline Australian National & 5 & 0 & Unknown \\
\hline Bond & 3 & 0 & N/A \\
\hline James Cook & 2 & 0 & N/A \\
\hline Macquarie & 0 & 0 & 0 \\
\hline Melbourne & 6 & 0 & 1 \\
\hline Monash $^{2}$ & 6 & 0 & 1 \\
\hline Murdoch & 0 & 0 & N/A \\
\hline Newcastle & $\begin{array}{l}\text { Inadequate } \\
\text { response }\end{array}$ & - & - \\
\hline Northern Territory & 2 & 0 & 0 \\
\hline Queensland & 4 & 0 & 1 \\
\hline $\begin{array}{l}\text { Queensland University of } \\
\text { Technology }\end{array}$ & $\begin{array}{l}\text { No } \\
\text { response }\end{array}$ & - & - \\
\hline Sydney University of Technology & $\begin{array}{c}\text { No } \\
\text { response }\end{array}$ & - & - \\
\hline Sydney & 0 & 1 & 0 \\
\hline Tasmania & 2 & 0 & 2 \\
\hline University of New South Wales & 12 & 0 & 11 \\
\hline University of Western Australia ${ }^{3}$ & Approx. 4 & 0 & 3 \\
\hline Wollongong & 0 & 0 & N/A \\
\hline TOTAL & 50 & 1 & 21 \\
\hline
\end{tabular}

Several matters are very apparent from this table. Of the current 
total law student body in Australia of about 11,000 only 50 are indigenous students. This represents less than 0.50 percent of the total law student body revealed in the survey. Equitable representation on a per capita basis would require there to be 150 indigenous law students, three times the current number.

Of the approximately 1,150 students pursuing postgraduate studies in law at the sixteen respondent law schools one only is identified as being of Aboriginal or Islander ancestry. Only two aboriginal law graduates, one currently enrolled and the other having graduated, have apparently ever enrolled for a higher degree in law. This under-representation in undergraduate and graduate numbers is troubling.

The total number of aboriginal law graduates in Australia, calculated to be twenty-one, is embarrassingly low. ${ }^{4}$ The University of New South Wales (UNSW) has provided over half of these graduates. This embarrassment becomes most apparent when one calculates the number of aboriginal law graduates required for equitable representation. Based on the 1986 Census figures, true representation would require there be some 1200 such graduates. It will be seen that this under-representation, when conflated with other survey results, would appear to be chronic and incapable of significant growth in the short to medium term.

Information about special entrance programmes and pre-law programmes was also sought from the Australian law schools. Table 2 represents the gist of the questionnaire responses.

With the exception of the University of Melbourne and the UNSW, the discretionary entrance schemes for aboriginal students are seen to be very recent developments. In the past ten years there appears to be a gathering momentum and, to 1990, eleven of the tertiary institutions have discretionary access procedures in place, either specific to the law school or broadly based university admission schemes.

TABLE 2

\begin{tabular}{lll}
\hline University Law School & $\begin{array}{l}\text { Special entrance } \\
\text { and year }\end{array}$ & $\begin{array}{l}\text { Pre-law } \\
\text { programme }\end{array}$ \\
\hline Adelaide & Yes, 1988 & No \\
Australian National University & Yes, 1990-91 & No
\end{tabular}




\begin{tabular}{|c|c|c|}
\hline Bond & No & No \\
\hline James Cook & No & No \\
\hline Macquarie & No & No \\
\hline Melbourne & Yes, 1968 & No \\
\hline Monash & Yes c. 1985 & No \\
\hline Murdoch & No, but planned & No \\
\hline Newcastle & $\begin{array}{l}\text { Response } \\
\text { inadequate }\end{array}$ & No \\
\hline Northern Territory & No & No \\
\hline Queensland & Yes, c.1984 & No \\
\hline $\begin{array}{l}\text { Queensland University of } \\
\text { Technology }\end{array}$ & No response & No \\
\hline $\begin{array}{l}\text { Sydney University of } \\
\text { Technology }\end{array}$ & No response & No \\
\hline Sydney & Yes, 1986 & No \\
\hline Tasmania & Yes, 1989 & No \\
\hline $\begin{array}{l}\text { University of New South } \\
\text { Wales }\end{array}$ & Yes & $1968^{5}$ \\
\hline $\begin{array}{l}\text { University of Western } \\
\text { Australia }\end{array}$ & Yes, 1988 & No \\
\hline Wollongong & $\begin{array}{l}\text { No, (but planned } \\
\text { in 1991) }\end{array}$ & No \\
\hline
\end{tabular}

Amid the plethora of disheartening data, the fact of growing access procedures is heartening. There is, it seems, increasing access to the law schools for Aboriginal and Torres Strait Islander students. The next step is success. Yet, the survey evidence as to the paucity of aboriginal law graduates from the law schools with the more established access schemes suggests something is awry. The University of New South Wales has produced eleven graduates in nearly 25 years of (informal and formal) discretionary admissions. Despite the longevity of the special entrance provisions at Melbourne University, it has produced but a sole graduate. The University of Queensland exhibits the same phenomenon. 
Mechanisms to allow aboriginal students to enter the law faculties are in place but few graduates are emerging successfully from these schemes. The efficacy of these schemes therefore needs to be examined with an eye on the fact that, as at the conclusion of the 1990 academic year, there is not a single preparatory pre-law programme, intensive or otherwise, in place in any Australian law school.

The questionnaire to the law schools sought information about discretionary admission schemes and, in particular, of the success or otherwise of such schemes. Because of the recent implementation of many of these schemes this a most difficult assessment and the question was generally not attempted by the respondents. However some guidance, it is submitted, is to be gained from critically assessing the performance of the UNSW in this respect. ${ }^{6}$

Between 1971, (from which time comprehensive records on Special Admissions were maintained) and 1990 there have been 57 Aboriginal student enrollments recorded in the UNSW law programme. The twelve students on the books in 1990 reduced this figure to 45 . Of these 45 students, eleven have graduated. This represents a student success rate of close to 25 percent. In other words, one in four Aboriginal and Islander students embarking on this LL.B. programme has succeeded with three out of four aboriginal students discontinuing their legal studies. ${ }^{7}$ From both the indigenous perspective and the law faculty administration perspective the high attrition rate would seem to be unacceptable. Couple this with the under-representation in the law schools noted in Table 1 and the acuteness of the problem is exposed. Based on the rate of discontinuance at UNSW only about twelve of the present 50-strong aboriginal law student body in Australia can reasonably be anticipated to graduate. At this rate of graduation the current number of approximately twenty aboriginal law graduates will take some seven years to double in number.

These calculations strongly indicate that, in general, the current access initiatives are failing, and seemingly will continue to fail, to achieve the intended results. Access programmes are vital, but, of themselves, are of little impact. With legal education in Australia facing many challenges the emergence of access procedures for aboriginal students to the law schools is a welcome development. 
But it would appear that, as stand-alone initiatives, their worth is extremely limited. If these schemes are to affect an equitable representation of aboriginal lawyers in the dominant legal system, they are not, to the present time, succeeding. This judgment is not intended to detract from the tremendous expenditure of energy which resulted in these initiatives. At an earlier point in time access may have been the primary issue. However, as the survey revealed, there are expanding opportunities for indigenous students to enter law schools through discretionary channels. The real stumbling block, at this point in time, is not getting indigenous students access to law school but ensuring that their chances of success is maximized. Participation in legal education means more than access to the law schools but entails success within the discipline of law. The access procedures must remain in place and other law schools encouraged to make similar initiatives. However, it is argued that, for the worth of these schemes to be fully realized, something additional is necessary. In the light of the Canadian experience, the most critical finding of the Australian survey is the total absence of a pre-law bridging programme for aboriginal students in any Australian law school. To compliment these access initiatives there is a compelling argument that an intensive national pre-law programme is very necessary. The dire absence of preparatory programmes for indigenous law students has been realized by several Australian law schools and will be returned to infra after an instructive review of the Canadian legal education of indigenous students.

\section{LEGAL EDUCATION FOR INDIGENOUS CANADIANS}

The inhospitable character of the Australian landscape for indigenous legal education is in strong contrast with the dynamic and fertile Canadian field. By way of general introduction, Canadian common law legal education has two channels of entry, the general and the discretionary. Unlike Australia, the general admission stream is based on the Law School Admissions Test (LSAT) and undergraduate results. Considerations which govern discretionary admission, though variable, are similar to those used in Australia, These include success at previous studies, maturity, background, work experience and the like. One obvious difference between Canadian legal education and Australian legal education is 
that the Canadian law student enters law school armed with an undergraduate degree and the law degree then takes a minimum of three years to complete. The standard length of the Australian LL.B. is four years but in many law schools there is direct entry to law school without the requirement of prior tertiary studies.

Most Canadian law schools have available discretionary channels of admission. The pertinent question, for the purposes of this paper, is what emphasis is placed on aboriginal persons in the general scheme of this discretionary channel. For information on this enquiry some assistance can be drawn from the research of Ms Patricia Monture, a Mohawk Nation lawyer, who wrote to Canadian law schools, both common law and civil law, in January 1990. Her general letter of enquiry asked for information "on affirmative action, access or equity programs in operation or within contemplation" of the law schools with a particular interest "in programs for racial and cultural minorities with a special emphasis on First Nation's peoples."8 Fourteen of the sixteen common law schools which responded to her enquiry indicated that they have "admission policies geared to the unique situation of First Nations in Canadian society.” In the absence of relevant background detail it is difficult to develop her results. She stated that:

There are four law schools which bear special mention. Dalhousie University in 1989, the University of Alberta in 1990, the University of British Columbia in 1984, and the University of Ottawa in 1989 have established directorships of special programs for First Nations and/or other minorities. The broadest based and the most progressive of these programs philosophically is the University of Ottawa. ${ }^{9}$

The University of Ottawa Education Equity Programme and Directorship will be briefly outlined as an example of these schemes. The Directorship was created with a mandate to increase the participation, at graduate and undergraduate levels, of individuals from groups currently under-represented in law faculties. These groups include aboriginal peoples, cultural and racial minorities, persons with disabilities, mature-age students and persons for whom economic hardship is a significant barrier to pursuing legal studies. With respect to aboriginal students, the stated goals of the Programme and Directorship are that admissions procedures are to be reviewed to remove systemic barriers, strategies are to be developed to recruit and reach the identified communities, and an academic support programme is to provide 
support to those indigenous students who are recruited. There is already an Aboriginal Advisory Committee to the Common Law Section. ${ }^{10}$ This Committee consists of two faculty members (presently one is a female aboriginal lawyer and the other an experienced teacher in the field of Aboriginal Rights), two aboriginal community leaders and five aboriginal lawyers. The Committee provides advice to the law faculty in all aboriginal matters including course development, student recruitment, public events and speakers, and scholarships.

To buttress the Directorship Ottawa piloted a pre-law programme for aboriginal students in the Summer of 1990. This pre-law programme is similar to other such programmes in Canada, being an intensive preparatory course in the Summer, but it is unique in that it is designed to assist French-speaking indigenous students and is essentially posited on the civil law schools (LL.L. studies). However, because the universities of Ottawa and Moncton also offer LL.B. studies in French the programme is designed to be flexible enough to assist French-speaking aboriginal aspirants to both common law and civil law schools. The skills preparation is directed to the Code-based Droit Civil of Quebec with necessary modification for those intending to pursue common law legal studies. ${ }^{11}$ The numbers in this Pre- Droit Programme are small with ten to fifteen being optimum. ${ }^{12}$

The Ottawa Pre-Droit Programme was the third such programme to be offered in Canada. To understand the phenomenon one needs to look at the earliest of these endeavours, the Saskatoon pre-law programme, the most successful pre-law bridging programme in Canada. ${ }^{13}$ Formally known as the Programme of Legal Studies for Native People, it commenced within the College of Law at the University of Saskatchewan at Saskatoon, Saskatchewan (hereinafter the Saskatoon Programme). The College of Law administered the Saskatoon Programme initially but this responsibility was assumed by the Native Law Centre (NLC) upon its foundation in 1975. The NLC had as a fundamental objective the development of the law and the legal system of Canada in ways which would "better accommodate the advancement of native communities in Canadian society.”14 Assisting aboriginal persons to gain access to, and succeed in, legal studies was given a high priority. The Programme of Legal Studies 
for Native People was the vehicle for this initiative. The initial purpose of the Programme was framed thus:

It is designed to orient students towards, and assist them in their subsequent studies in a regular law program in any Canadian Law School. While the curriculum involves studies in standard first year courses the intent is to acquaint each student with the methodology of the discipline rather than to require mastery of any given amount of material. ${ }^{15}$

Entry to the Saskatoon Programme is restricted to students of aboriginal ancestry from across Canada. Prior to 1988, the Programme attempted to simulate the first year law experience. The five first year subjects commonly taught in Canadian law schools, (Torts, Criminal Law, Property, Contracts and Legal Writing \& Research), were taught intensively over an eight week period. Then, in 1988, a greater emphasis was placed on skills development and the substantive courses reduced to three. Nonlegal writing specialists were brought in on consultancies and in 1990 indigenous Elders were introduced into the Programme to provide students with counselling assistance and spiritual guidance. Policy requires that before a candidate is admitted to the Saskatoon Programme, he or she must be conditionally accepted to a Canadian law school by either the discretionary or general admission channel. At the completion of the Programme an assessment of the potential of each student to succeed in law school is made and recommendations for legal studies granted to suitable alumni. The concurrence of the Canadian law schools, principally utilizing the discretionary channel of entry, is thus necessary for the continued utility of the Saskatoon Programme. It is quite common for law schools to make it a condition of admission that the aboriginal applicant successfully complete and achieve a recommendation from Saskatoon before entering their law school. The law schools look to the Saskatoon Programme to prepare these students for the law school experience and to provide a solid skills basis upon which the individual law schools can build. The Programme therefore has a close association with interested Canadian law schools.

The preparatory function of the Saskatoon Programme is complemented by its assessment function. It not only provides a "headstart" for those students who receive a recommendation to law school but usually suggestions are made to those who are not 
so recommended to undergo more preparatory studies.

The Saskatoon Programme was first offered in the Summer of 1973. The initial enrollment was fourteen students. The enrollments grew to 20 in 1978, in 1983 to 58 and in 1990 there were 53. The alumni of this programme started to graduate from law schools at the end of the Spring trimester of 1976. During this time and to the end of 1990 there have been 138 alumni who have continued to successfully complete a law degree. ${ }^{16}$ The breakdown, in terms of year and number of aboriginal law graduates is set out in Table $3 .{ }^{17}$

TABLE 3

\begin{tabular}{ll|lc}
\hline 1976 & 4 & 1984 & 14 \\
1977 & 7 & 1985 & 9 \\
1978 & 3 & 1986 & 10 \\
1979 & 8 & 1987 & 7 \\
1980 & 6 & 1988 & 14 \\
1981 & 2 & 1989 & 14 \\
1982 & 7 & 1990 & 20 \\
1983 & 13 & 1991 & - \\
\hline
\end{tabular}

With approximately 160 aboriginal law graduates in Canada to the end of the 1990 academic year these 138 alumni represent over 75 percent of all successful law graduates. Stated in another and quite telling manner, only 22 of these 160 aboriginal law graduates in Canada have succeeded without Saskatoon preparation.

These figures do not evince the rate of success of these Saskatoon alumni once substantive legal studies have been undertaken. Exact figures are unavailable yet some indication can be gleaned from re-working the available statistics. ${ }^{18}$ To the end of the programme in 1989 some 469 aboriginal students from across Canada had been admitted to the Saskatoon course. Twenty have withdrawn. Of the remaining 450, 308 alumni have been recommended to Canadian law schools with 292 actually enrolling in LL.B. courses. To the end of 1989 the number of successful alumni was 118 with the alumni of 1987, ' 88 and ' 89 still in the 
pipeline. This would indicate that approximately one in two of the recommended alumni went on to successfully complete substantive legal studies. Success in the Saskatoon Programme is thus a 50/50 proposition for success at substantive legal studies.

However, more recent figures suggest that this may be a very conservative estimate only. To the end of 1992, 461 alumni have been recommended by the Saskatoon Programme to law schools studies. Of this number 450 have gone on to enrol in a law school. To the end of the 1992 academic year, 187 have successfully graduated from law school. There are another 80 students in first year law school, 51 in second year and 44 in third. This means that of the 450 alumni who pursued law studies 187 have vindicated the recommendation of the Programme and another 175 are still in the law schools. This represents a retention rate of 80 percent and suggests a success rate of three in four alumni. Moreover, in the three years from the end of 1989 through to the end of 1992 nearly 70 alumni of the Saskatoon Programme have graduated from law school.

It is important to iterate that the Saskatoon Programme is an operation which services law schools across Canada. To the end of the 1989 academic year, only twelve of the alumni of the Programme have stayed on at Saskatoon to successfully complete their legal studies. The vast majority have gone elsewhere with UBC having graduated 36, and both Osgoode Hall at York and Queen's having graduated seventeen. The least successful law schools are Toronto, Dalhousie and Calgary, which have only one aboriginal law graduate apiece. Windsor and New Brunswick, at that point in time, had no aboriginal graduates in law.

The direct annual cost of the Programme, excluding administrative support is in the range of $\$ 90,000-120,000$. The administrative support adds another $\$ 70,000-80,000$. This is mitigated by the imposition of a substantial student fee for the programme of, currently, $\$ 2500$. This is usually paid by sponsoring agencies, such as individual Indian Bands, tribal educational bodies, or Federal government departments. Fees are sometimes waived for needy students for whom funding is unavailable. ${ }^{19}$ The degree of support for the Saskatoon Programme in the Indian, Metis and Inuit communities and by its alumni is very high. It is regarded as an "institution" and any attempt to dismantle it would 
meet with strident indigenous resistance..$^{20}$

Two other law schools in Canada now have pre-law programmes in place, the previously-mentioned Ottawa Pre- Droit programme and the other at Dalhousie University Law School. Dalhousie Law School, established in 1883, is the oldest Canadian common law school. However the law school could, until recently, boast of merely one indigenous graduate in over one hundred years of continuous operation. In 1989, in order to redress this imbalance, it established the Law Programme for Indigenous Blacks and Micmacs (the IBM Programme). The ambit of the IBM Programme, unlike the Saskatoon Programme already outlined, is specific to Nova Scotia and restricted to indigenous Blacks and Micmacs resident in Nova Scotia. It is "to increase the representation of Indigenous Blacks and Micmacs by making Dalhousie Law School more accessible to applicants of these two communities." ${ }^{21}$ Its primary goal is to recruit more students from these communities to remedy the "historical inequality" of their under-representation in the legal profession. The Law School is also committed to "a modification of the present educational system by introducing minority or previously excluded perspectives on the [Canadian] legal system" and the recruitment of law teachers from the Indigenous Black and Micmac or other minority communities. $^{22}$

A preparatory programme is offered, with continuing financial and academic support throughout the following three years of legal studies. The pre-law programme is month-long and offered in August to prepare for the Fall entry of the students into Dalhousie Law School. Admission to the IBM Programme is based on the writing of LSAT, academic background, community involvement and other information such as reasons for seeking to pursue legal studies and employment history. The initial programme was offered in the Summer of 1990 and this represented the second common law based programme in Canada ${ }^{23}$. Ten applicants (6 Indigenous Blacks and 4 Micmacs) to the programme were accepted into First Year Studies in 1990-91. This was projected to rise to twelve (7 Indigenous Blacks and 5 Micmacs) in 1991-92 and to be maintained at that level for some years.

The academic requirements for these students for graduation from Dalhousie Law School is, it is to be stressed, the same as 
other students. However, the course structure in First Year, which consists entirely of mandatory subjects, is amended for these entrants. One such course is held over until the completion of the Spring examinations and offered as an intensive course in May of each year. Daily tutorials are offered to these entrants during their initial year with individual student tutors assigned to each programme entrant. Second and Final Years requirements are the same for all students. The IBM Programme Brochure states that during these latter years the entrants are "pretty much on their own”. Some tutoring, dependent on funding, may be available but it is envisaged that relatively independent study would be pursued after First Year.

The IBM Programme hence adopts a combination of strategies. One important distinction between the Dalhousie pre-law programme and those of Saskatoon and Ottawa is that the entrants to the programme continue on to first year studies at Dalhousie where placement in the law school quota is assured. The students are already admitted to the law programme and this is really an internal preparatory scheme but with a screening process. There is some measure of experimentation and the implementation of the programme has not been without considerable debate. The success or otherwise of this approach is far too early to assess.

\section{A PRE-LAW PROGRAMME IN AUSTRALIA?}

There is a pressing argument that an intensive pre-law programme for indigenous Australians is very necessary. The absence of such a preparatory programme, it is submitted, is a glaring omission which the Canadian evidence clearly evinces, requires immediate remedy. The Saskatoon Programme can boast of preparing some 138 of the 160 aboriginal Canadian law graduates to the end of 1989. The success rate of the alumni of the Saskatoon Programme is conservatively calculated to be one in two, double the UNSW figures. I believe the contrast stark and the argument for a similar fast-track skills development programme in Australia compelling.

I find support for this view, not merely from the contrast of the Canadian and Australian survey materials, but also from additional comments provided in the course of the survey. In the covering letter to the questionnaire all Deans were asked to provide critical 
comments and any additional materials they, or their representatives, deemed relevant. These comments, most helpful in identifying areas of concern, came principally from the Queensland law schools, especially the University of Queensland.

The Aboriginal and Torres Strait Islander Studies Unit (ATSISU) at the University of Queensland was established in 1983 to operate programmes to assist aboriginal students in access, counselling and study skills acquisition. The Unit's programmes are broadly directed and integrated. Without commenting on the success of the ATSISU initiatives in other disciplines, the programmes have not seemingly assisted Aboriginal and Islander students within the Law Faculty. A special entry scheme for Aboriginal and Islander students has existed within Law Faculty since $1983 / 4$ but, to the end of 1990, no graduate has successfully emerged as a result. ${ }^{24} \mathrm{Mr}$ Denis Brosnan, Administrative Officer to the Law Faculty, stated in his covering letter to the questionnaire that:

[T]he special entry program is neither large nor conspicuously successful. Steps are being taken to address the latter. Aboriginal students apply for entry through the Queensland Tertiary Admissions Centre (QTAC), entering a code on their application forms which identifies their background to University staff acting as assessors at QTAC. The assessors bring this information to the attention of the Dean [of Law] and of the Aboriginal and Torres Strait Islander Studies Unit. Staff from the Unit then arrange for applicants to provide further information, and each applicant is then interviewed by staff from the Unit and from the Faculty of Law. It is not uncommon for only half of the applicants to attend for interview. No interview, of course, means no place in Law.

On a number of occasions, reasonably promising applicants who have fallen considerably short of the regular cut-off score have been admitted directly to the LL.B. program. For various reasons, most have not been successful. It has been decided that such applicants should be strongly encouraged to take one year of, say, B.A. study, on the basis of which they will be reconsidered for Law. They may take whatever subjects they like, and [...] are certainly expected to pass. This has the two-fold advantage of preparing them for a rigorous discipline by easing the transition to tertiary study, and of avoiding the waste and disappointment which may result from throwing them in at the deep end. [Emphasis added] ${ }^{25}$

This “deep end” metaphor appears to have a certain reality for the indigenous law student. The need to adequately prepare aboriginal students for the study of law is also borne out by the 
remarks of Marylyn Mayo of James Cook University (JCU) in her covering letter for the questionnaire. The small Department of Law, under the directorship of Ms Mayo, taught First Year legal subjects only for many years. Those wishing to continue with legal studies had to go to other institutions or study externally. Second Year was added to the law programme in 1989. The Department set a full programme in place in 1991 and graduated its first alumni in early 1992. Ms Mayo says:

Over the years, I have had a number of Aboriginal students in first year and have given every encouragement to their entry and continuance. Only two have continued into second year. One of these took two years to pass the first year subjects, and [had] great difficulty with second year. The other first year students often worked in the Aboriginal Legal Aid Office and were provided with extra tutorials by the Department [of Employment, Education and Training]. I attribute their failure to poor school education (especially a lack of reading and writing skills) and possibly the lack of support mechanisms within the University. I have noted personal and psychological problems, lack of diligence and motivation and reluctance or inability to communicate with the counsellors or myself. ${ }^{26}$

With a small student body and as both administrator and law teacher, Mrs. Mayo probably had a closer understanding of her students than the larger law schools. Her observations point to poor pre-tertiary schooling, which cannot be directly addressed in this paper, but is a matter of utmost concern. It is an initial stumblingblock for indigenous access to all manner of post-secondary education and her observation underlines the need for adequate preparation of these students for tertiary education in general and the law school experience in particular. ${ }^{27}$ Her comments also highlight the need for an integrated support scheme within the tertiary institutions. In addition, the University of Melbourne response also noted the "[e]ntrants are experiencing difficulty with Law subjects” and noted that extra tutorial support was being provided.

Other matters prompted by the survey also add credence to this argument. The survey was brought to the attention of the Director of ATSISU, Mr Allan Sambono, by the Law Faculty. In a responding letter addressed to Mr Sambono noted two aspects of the questionnaire which warranted particular attention. ${ }^{28}$

The first relates to Question 4 regarding a pre-law program. I would like to know if there is the possibility that such a program may be instigated 
here at the University of Queensland. I believe there are many potential law students in the Aboriginal and Islander communities who [...] need a course which prepares them and gives them the foundation to participate in mainstream law course. Such a course could involve among other things, attainment of skills required as a law student, and an introduction to the structure and operations of the legal system. It is a vital step towards opening up the study of law to the Aboriginal and Torres Strait Islander students. Needless to say the Unit will assist in all possible manner to establish and conduct a pre-law program. ${ }^{29}$

The above comments recognise that adequate preparation of aboriginal students for the law school experience is not so much desirable but most necessary. The need is obvious, in my submission, to lessen that initial leap into the "deep end with a prelaw bridging programme.

There are at least two bridging methods which could be adopted to this end. These are the year-long orientation schemes such as the Monash Orientation Scheme for Aborigines (MOSA) at Monash University or an intensive model such as the Saskatoon Programme. The former is general in that it would prepare the student for tertiary studies, the latter is legal-studies specific. MOSA, for example, offers aboriginal students "specific preparation for university study, bridging the educational and cultural gap which frequently exists between Koori people and other first-year university students." ${ }^{30}$ In most cases applicants are expected to have completed Year 10 and be over the age of 21 years. There are two strands, the year-long Humanities Orientation and the Science Orientation Programmes, the latter being over two years. Apart from MOSA and ATSISU, broad access and orientation programmes are being put in place at various tertiary institutions. The University of Western Australia has the Aboriginal Participation Initiative (API) which provides for some students to enter degree courses with standard matriculation but which envisages most aboriginal students entering through a discretionary scheme which has a bridging programme of one full academic year which gives matriculation status after the successful completion of that year. These students then move into their degree programme of choice. The University of Queensland response to their poor success rate, of strongly recommending one year of Arts studies prior to commencing legal studies, is common to several law schools but is really an ad hoc mechanism for achieving this orientation. 
The other method, particular to legal studies, is to require an intense orientation programme of six to eight weeks on the Saskatoon model. The relative merits of each, with law school preparation qualifying the discussion, is open to debate and legal educators may be best positioned to conduct that debate. Both approaches appear meritorious and can be complementary. It may be that in some cases basic literacy and numeracy skills have not been imparted to otherwise intelligent students that the wisest course of action is to adopt the longer term approach to ensure that the necessary skills for tertiary studies are acquired. It may also be that both a broader, longer-term approach and a short intensive legal-studies specific course may serve cumulatively to best prepare the prospective indigenous law student.

But the need for a fast-track skills preparation scheme for legal studies, I would suggest, is most pressing. There are two principal reasons. The MOSA and API initiatives, for example, are particular to the specific institution and are regional in their focus, not unlike the Dalhousie model. ${ }^{31}$ These models necessitate that aspirants from without the region reside away from their country or family. In reality, this offers little to the indigenous person in (say) Broome, Katherine, or Palm Island with a desire to enter upon legal studies. Prolonged physical separation will certainly derogate from the desired success for these students. What is required is to draw together for a short period a critical mass of indigenous aspirants, (who share a common goal and can provide support for each other in their common endeavour), for a preparatory programme and who can then return to pursue their legal studies as close as possible to their country or family. Aboriginal and Islander consultation, I would submit, will underscore the very substantial weight to be given this factor.

The second reason is the nature of the studies to which the programmes are directed. Completion of MOSA Humanities Programme guarantees first year places in the Faculties of Arts, Economics, Politics or Law. The Programme does not equip an Aboriginal or Islander student specifically for legal studies. The poor rate of success, if the UNSW figures are to be any guide, and the comments from JCU, Queensland, Monash and Mr Sambono from ATSISU, suggest both that general skills preparation for aboriginal law students and the need for a legal-skills specific 
programme are necessary.

Impetus for an intensive pre-law programme in Australia also comes from the Australasian Law Teachers Association (ALTA) conference held in Perth in July 1991. The subject of the legal education of indigenous persons was discussed and a resolution was passed at the Annual General Meeting. Recognising the few persons of aboriginal descent are admitted to legal studies, that fewer persons of aboriginal descent graduate successfully from law, and that the Canadian Program of Legal Studies for Native People [the Saskatoon programme] has had some success in improving the rate of graduation in law of aboriginal persons and their representation in the legal profession, it was resolved:

That the Australian Law Teachers Association supports the establishment of an intensive, short-course, bridging Australian Programme of Legal Studies for Aboriginal [and Islander] Peoples at one or more Australian Law Schools. The course should be a pre-law programme specifically directed to the development of the skills necessary to succeed in law school. The Executive should seek, in conjunction with Australian law schools, to implement this resolution. ${ }^{32}$

It is imperative that the solid base of discretionary admission procedures in the individual law schools be maintained and broadened for the prospective aboriginal student to gain maximum utility to any such pre-law programme. The relationship between a skills acquisition programme and the discretionary schemes is interdependent. Each is advantaged by the other. The pre-law programme is to be seen as a conduit of preparation of aboriginal students for legal studies in all Australian law schools which support this initiative. Without this back-drop the efficacy of any pre-law programme would be severely curtailed just as without the orientation programmes, fast-track or otherwise, the efficacy of the access schemes will remain limited.

\section{CONCLUSION}

The first schemes to encourage indigenous access to Australian law schools were in the late 1960s. Other such welcome schemes have since been instituted and are being directed to correct the iniquity of representation of aboriginal persons in the legal profession. These schemes are increasing rapidly. Presently, however, these schemes are not achieving the desired result. To the 
end of 1990, admissions have only resulted in just over 20 indigenous law graduates and, it must be remembered, not all of these graduates were entrants via these schemes. One Aboriginal person has successfully obtained a higher degree in law and another is in the throes.

The conclusion to be drawn is that Aboriginal and Islander students have failed to successfully pursue legal studies despite not insubstantial efforts on the part of the legal educators, the law schools and, of course, the indigenous students themselves. The future, given present indications, offers very little by way of amelioration of the embarrassingly low number of indigenous graduates. It has been argued that the absence from Australian legal education of a pre-law programme is a most telling factor in the lack of numerical success for indigenous students despite increased aboriginal access to law schools. The efficacy of the access schemes, in my submission, will continue to be so limited without such a pre-law programme. The time is ripe, given the education emphasis of the recently established Aboriginal Reconciliation Council, for pressure to be brought to bear and the necessary funds found for this further step. Priority should be given to the establishment of one such fast-track pre-law programme in Australia.

A basic blueprint of an Australian model, forwarded to prompt discussion, should be, in my submission, along the following lines. The model should be posited on the Saskatoon model with one such programme to be offered annually after the conclusion of one academic year and continuing to near the start of the next. ${ }^{33}$ It requires a six to eight week time frame. The support of as many interested law schools as possible should be sought. This will maximize intake and eventual placement and it would also assist to co-ordinate and to achieve the maximum utility of the burgeoning access endeavours at the various institutions. Priority of acceptance should perhaps be given to those students who have successfully completed generalised orientation courses such as MOSA and API. A course structure encapsulating an overview of the Australian legal system, common law methodologies, adumbrated first year courses, the acquisition of research and writing skills. All of these matters and more would need to be worked out in consultation with the law schools which support the Programme. The preparatory 
function of the Programme will be complimented by the assessment function. It will be both an important "headstart” for those students who receive a recommendation to law school and screen those who are unable to achieve a recommendation and to whom it is suggested that more preparatory studies be undertaken if they wish to pursue legal studies.

Recommended alumni of the programme would head off to the supportive law schools to pursue first year legal studies, the individual law schools picking up the academic responsibility for the student, the universities and indigenous support structures the responsibility for matters of non-academic concern. The first year curriculum may have to be amended on the Dalhousie model to allow for the transition. Mandatory tutorial assistance over the first two years would be most advantageous. Comment on any initiatives should be sought from Aboriginal and Islander communities and organisations, (and also those Aboriginals and Islanders who have graduated from law school), in the early stages of any proposal and this consultation should be structured on the abovementioned Ottawa model at the individual law schools.

The intensive Saskatoon Programme has served indigenous Canadians very well in its nearly twenty years of operation. Only in the past three years have alternative, regionally-based models started to emerge. It may be, in the absence of undergraduate studies in Australia prior to entering law school, that the longer course models will be more efficacious to indigenous Australians than the short-course intensive Saskatoon model. However, all these year-long (and longer) models are regionally focussed. What happens whilst these regional models are being initiated and developed? There is still a need in Australia for a national intensive preparatory programme on the Saskatoon model until such time as every jurisdiction has a preparatory programme in law. In my submission, there is a discernible need for an intensive programme a la Saskatoon even if such an intensive programme has written into its structure a limited life span of, say, ten years. If, after these ten years, there are sufficient regionally-based programmes to form a national network then the intensive programme can be wound down.

For the Aboriginal and Islander law student there are enormous challenges, not merely scholastic, to the law school experience. The 
JCU observations clearly state the difficulties of the law school experience for indigenous students and the need for an integrated support scheme within the tertiary institutions. The physical needs (accommodation and the like), the psychological needs including the cultural differences (an understanding by both the student and the Faculty of the cultural alienation the aboriginal student may have to overcome), and the academic needs (extra-curricular support, skills acquisition, etc.); all these matters have to be considered.

Indigenous law students currently face being educated in another cultural tradition. Law is a bastion of that other cultural tradition which has traditionally ignored them. Education is another and in this sphere they have faced marginalization. The combination represents a formidable cultural obstacle not easily scaled. However, there has a greater realization that the law school experience, which gives an understanding of the dominant legal and political processes, is a significant means of ethnopolitical empowerment, both for the individual and collectively. The words of the late Chief Dan George eloquently speak to the position of these students. Although the elderly Chief believed that the only weapon left for him to wield in his declining years was the power of speech, he did not underestimate this faculty: "It is only with tongue and speech that I can fight my people's war." ${ }^{34}$ His words are as relevant to Aboriginal and Islander peoples of Australia as they have been to indigenous Canadians:

There is a longing in the heart of my people to reach out and grasp that which is needed for our survival. There is a longing among the young of my nation to secure for themselves and their people the skills that will provide them with a sense of worth and purpose. They will be our new warriors. Their training will be much longer and more demanding than it was in olden days. Long years of study will demand more determination, separation from home and family will demand endurance. But they will emerge with their hand held forward, not to receive welfare, but to grasp the place in society that is rightly ours. ${ }^{35}$

* Barrister. I wish to express my appreciation to the Deans of the respondent Australian law schools for their helpful participation in the survey. I would also like to thank Brad Morse, Garth Nettheim, Richard Bartlett and Graeme Cooper for their guidance and valuable comments on the draft. (C) 1993. (1993) 4 Legal Educ Rev 177.

1 Torres Strait Islanders will be abbreviated to Islanders. Uncapitalized the term aboriginal will mean indigenous, thus including both indigenous peoples of Australia. The word native has such poor historical connotations that it will be 
eschewed unless used by another source or in a title of a work or programme.

2 Representatives of Monash have since challenged the formal survey response of six and placed the number at ten. It would appear that the divergence can be explained by the fact that some aboriginal students have deferred their legal studies to complete Arts or other degrees, are not thus currently enrolled in law subjects but remain "on the books" of the Faculty. These students were correctly omitted from calculation by Monash. Those not studying law subjects in 1990 do not fall within the parameters of the survey.

3 The formal response was that "at least" three students entered through the Aboriginal Quota and "at least” one other student through the normal entry procedures.

4 This exact figure must be regarded with some skepticism as two respondent law schools, Monash and Tasmania, made certain errors on the questionnaire when replying to this specific enquiry. Their errors have been corrected.

5 An informal special admission procedure for indigenous students operated from as early as 1968 but was not formalised until 1989.

6 The UNSW is the undoubted leader in the field of Aboriginal Rights in Australian legal education. Their laudable initiatives bear some critical examination and provide as good a litmus indicator of the efficacy of theses schemes as is presently available. The Aboriginal and Islander Special Admissions Scheme has been in formal operation since 1989 but since about 1968 indigenous students could gain admission to the law school on discretionary grounds by direct application to the Faculty or through the Counselling Unit. This Faculty was the first to offer a law course in Aboriginal Rights. Aboriginal legal issues are well integrated in the remaining curriculum. There has been an Aboriginal Student Centre within the University for over eight years. The Law School houses the Aboriginal Law Centre which publishes the Aboriginal Law Bulletin and maintains a research collection specializing in aboriginal peoples and the law. In the 1980s it sponsored or assisted at least five major conferences in the field. Teachings materials have been published and made available to other post-secondary institutions. A valuable text, Aboriginal Legal Issues: Commentary and Materials was published in 1991. H McRae, G Nettheim \& L Beacroft, Aboriginal Legal Issues: Commentary and Materials (Sydney: Law Book Company, 1991).

7 This computation neglects those students who complete their legal studies elsewhere. Given the small number of students to start with this number would be small indeed. Other students, it has been pointed out by Professor Nettheim, are drafted into government service and never complete their studies.

$8 \quad$ P Monture, First Nations and the Law School Experience (1990) 15 Queen's LJ 179 at 197.

9 Id at 198. Regrettably few details of these programmes are given. Also, the University of Manitoba, not mentioned in this list, initiated a special programme for aboriginal peoples in 1990.

10 The Law Faculty at the University of Ottawa is bijuridicial, there being both a Common Law Section and Civil Law Section.

11 Conversation with Professor Jean-Paul Lacasse, the Director of the Pre-Droit Programme at Ottawa, on 28 June 1991.

12 The pilot Pre-Droit Programme had thirteen students all intending to enter into Droit Civil LL.L. programmes. The 1991 Programme had twelve members, only two of whom were intending to pursue LL.B. programmes in French.

13 The Saskatoon Programme is modelled on the experience of the University of New Mexico in the United States.

14 An Overview of the University of Saskatchewan Native Law Centre (unpublished manuscript prepared for the Dean's Review Committee of the Native Law Centre by the Director of the Centre, October 1990) 1. 
Id. at 5.

16 Id. at $4-5$.

17 The information is tabulated from statistics appended to Purich. Id.

18 These figures are also drawn from the statistics appended to Purich. Id.

19 Id at 5.

20 Conversation with Mr Roger Jones, past President of the Indigenous Bar Association of Canada and an alumnus of the Saskatoon Programme, Friday 28 June 1991.

23 The University of Ottawa also offered the pilot Programme Pre-Droit in the Summer of 1990.

24 Happily, the first graduate was in early 1992.

25 Letter to the writer dated 28 March 1991.

26 Letter to the writer dated 5 December 1990.

27 This has been highlighted in a recent study in Canada. The registered Indian population are three times less likely than non- Indians to enter upon university studies. The primary reason forwarded for this situation is the relatively poor rate of Indian students who successfully complete secondary school. See R Armstrong, J Kennedy \& P R Oberle, University Education and Economic WellBeing: Indian Achievement and Prospects (Ottawa: DIAND, 1990) at 12.

The other matter Mr Sambono raised, of importance but not to be addressed here, was the need for conferences dealing with aboriginal legal issues to be held. He stressed such initiatives require the involvement of the legal community and the Aboriginal and Islander communities.

29 Letter to Mr Denis Brosnan from Mr Allan Sambono dated 25 March 1991. The response of the Law Faculty to this suggestion for a pre-law programme is unknown.

30 Unpublished brochure for MOSA programme, at 3.

31 Monash states that, through the MOSA initiative, it has accepted national responsibility for access to tertiary qualifications for aboriginal people. Some doubt must exist as to whether it can adequately discharge this responsibility given the multitude of facets or whether this is indeed a desired position.

32 Resolution moved by Professor Garth Nettheim, seconded by Professor Richard Bartlett, passed at the Annual General Meeting of ALTA on 14 July 1991 in Perth, W.A.

33 The ALTA Resolution speaks ambitiously of more than a single such programme.

34 It is of some relevance that in the June 1991 election of the Grand Chief of the Assembly of First Nations, arguably the most powerful indigenous organization in Canada and representing 500,000 "status" Indians, the successful candidate, Mr Ovide Mercredi, was a graduate of the University of Manitoba Law School.

35 D George \& H Himschall, My Heart Soars (North Vancouver: Hancock House, 1974) at 91. 